\title{
PRELIMINARY REPORTS
}

Jaroslava Radojević

$796: 006.3 / .8$

Preliminary report

Faculty of Sport and Physical Education, University of Belgrade

\section{STANDARDS IN FUNCTION OF QUALITY PROMOTION IN PHYSICAL EDUCATION}

\begin{abstract}
Within the Standards for completion of compulsory education, elaborated by the Institute for education quality evaluation, adopted in 19th May 2009 by the National Educational Council of Serbia, there are standards for ten teaching subjects, PE included. The aim of this paper is to introduce them, immediately before the adoption of the standards, possibly before their publishing in the Official Journal, to the professional public as well as to prepare and activate them fir the process of their incorporation and application in practice. The paper considers the basic features of PE standards: testability, direction at fundamental knowledge, abilities and skills; accumulation (taking into consideration contents of both elementary education cycles); differentiated approach to students; feasibility and obligation. By comparative analysis of a formulated, valid aim of PE, of syllabuses for elementary education and recommendations for the way of its realizations and features of educational standards for completion of elementary education, in which educational aims and tasks are concretized through students - acquisitions - outcomes visible in both behaviour and reasoning, the answer is given to the question of how to achieve better effects, increase PE quality with the capacities we have at our disposal. Directed at: ability in skills; knowledge on physical exercises and physical education by the, the standards objectively assessment, making thus the marks comparable and provide foundation for further development of self-evaluation instruments. One the major contributions of realization of instruction process in compliance with the educational standards is activation of teachers, students, parents and school. The paper also presents the dilemmas related to concrete problems in PE educational field (subject), primarily in conditions for realization of PE syllabuses as well as realization of instruction contents within the first cycle of elementary education, which however shall directly reflect to possibilities of standard achievement for completion of compulsory education. Thus, the need is stressed to adopt the standards but also to ensure their full realization ay the end of the first cycle of elementary education
\end{abstract}

Key words: STUDENTS / COMPULSORY EDUCATION / LEARNING PROCESS / ENDING

\section{INTRODUCTION}

Within the Standards for completion of compulsory education, elaborated by the Institute for education quality evaluation, adopted on $19^{\text {th }}$ May 2009 by the National Educational Council of Serbia, there are standards for ten teaching subjects, PE included. The aim of this paper is to introduce them, immediately before their adoption, possibly before their publishing in the Official Journal, to the professional public as well as to prepare and activate them for the process of their incorporation and application as well as to highlight opportunities related to improving the status and functioning of essential segments, significant for physical education. The publication, „Mandatory standards for completion of compulsory education" defines the standards as:" ... statements about the fundamental knowledge, skills and abilities that students should acquire by certain level of education. The standards articulate the most important 
demands of school learning and teaching and present them as the visible outcomes in student behavior and reasoning"(Čarapić, G. 2009th, p.5).

As instruments of the overall educational process, the standards deal with its most sensitive part - the outcomes and become part of the mechanism of quality assurance. Educational standards for completion of compulsory education have the character of final evaluation. However, the Law on the Bases of Education System, provides special standards of achievement, established according to age, grades, subjects or modules based on the general outcome of education and general standards of achievement (Art. 5, paragraph 6). For physical education, it would be important to formulate procedural standards as part of evaluation that is performed earlier and provides opportunity to affect further course of educational process.

Physical education is often featured by provisionally and scientifically unfounded judgements, with highly negative assessment of material working conditions, the work of teachers and contents of the program, through statements that our physical education corresponds to our general education, but also with positive assessment, based on good practices. We do not know for certain what the real situation is and which of the aforementioned PE characteristics prevails.

Although in physical education there were, and still exist, the criteria on assessment of the success of students, teachers and schools, until now there was no systematic, based on generally accepted standards, evaluation process of outcomes after a certain level of education at the relation: goal, tasks, outcomes and standards. Therefore, it was not possible to conduct objective self-evaluation, as well as to compare one's own results with the results of others at the level of schools, local self-government or broader, national level. These processes will be enabled by using the national standards. However, it should be considered that when it comes to physical education, meeting of the standards depends on a number of factors that dictate the adjustment and, in many schools, reduce the possibilities of their realization.

The necessity to establish evaluation of education process and PE (sports) education as its part, in the sense of today's interpretation, is defined in the analysis published in 1996 (more than ten years ago, and it refers to a period of ten years prior to the pub- lication): „Ten years of the reforms of compulsory education (1984-1994) in some European countries (Eurydice, 1996). Several notions were described there: the strategy of thinking and problem solving, and communication technique (Luxembourg), learning strategy (Spain, Italy, the Netherlands), taking account of individual needs (United Kingdom), and development of an individual in his integrity (Denmark), directing of the focus towards the feeling of well-being and pleasantness (Austria, France, Belgium). In the period from 1984-1994 minimal educational requirements appeared as precursors to $\mathrm{PE}$ outcomes. Since 1984, even our PE syllabuses have defined, as part of the program wholes, the minimum educational requirements for each subsection of each grades, which indicates that the profession followed the PE tendencies even outside the country.

The conclusions of numerous studies, theoretical and professional debates at the end of the last and beginning of this century, discussed the problems of physical education in school. The highest European Union authorities (Council of Europe), conferences related to large sporting events, European, regional and national political and scientific meetings, established a „crisis of physical education” and suggested various solutions, some of which were been applied in practice, but some remained at the level of theoretical debate. This was a period of live activities, while in our country, for a variety of objective and other reasons, there was stagnation or decline in the material basis and quality of $\mathrm{PE}$ teaching process.

Recent reports on the organization and the state in physical education on one side and in sports system on the other side in 26 European countries, as well as a detailed analysis done (Klein and Hardman, 2008) show a different position and PE goal defining within the national curricula. Reports and analysis, which in parallel with consideration of the position, PE goals and tasks, discuss also the elements of sport organizations, as well as the links between the educational system and the system of sport, show that, with certain differences, there are many problems that we also recognize in our country. However, with three classes of physical education in the first of and three in the second educational cycle (two classes of physical education and one class of compulsory elective subject: Physical education - selected sport), extra- 
curricular activities and school sports, we can say that physical education is currently well positioned in the educational system, and that this positions should be defended, maintained and that a lot of energy should be invested to achieve better quality physical education. Today, in the curriculum for older grades of primary school there is one class (the third one of the weekly number) Physical education - selected sport, as compulsory elective subject. However, it does not mean that it will remain. Possible changes, which for example, occurred in Slovenia, should be anticipated and opposed in advance:

„We (teachers and pupils) lost 1 lesson per week in higher grades (7-9), they have only 2 , hours " per week. I think that is not good idea, because pupils have more and more health problems and weight problems is becoming bigger problem also; facilities: some schools have really old and bad sport halls and equipment; that is not enough for quality teaching, so pupils in those schools may lack possibility of large sport knowledge; pupils do not like sport anymore, they rather decide to stay at home and work and play computers; that's why teaching is becoming harder and pupils physical fitness dropping rapidly; more and more pupils have some kind of disability, teachers have to deal with those problems on their own ". (Klein and Hardman 2008., p. 14).

So many times, in different formulations repeated statement that modern way of life brings insufficient movement and consequences: obesity, body posture disorders, juvenile diabetes and cardiovascular diseases, that is all non-infectious chronic diseases, as well as psycho-social problems, would be misused if it were not ,painfully” correct, and if it were not generated, at junior school age.

Why talking about all these issues in considering the introduction of standards in physical education at the end of compulsory education? Because the process of physical education, outcomes and standards can hardly be achieved unless there is vertical correlation of teaching contents and outcomes, at least in cycles. Often insufficient or "no" realization of PE in the first educational cycle - with exceptions, has always (for 60 years) been a problem, which, in higher grades - the second cycle, was almost impossible to overcome. As for other educational fields, PE work at junior school age is of immense impor- tance. It is possible that a quality physical education at a younger age, would affect creation of habits and needs of students for physical exercise, and thus would avoid, to such an extent, the manifested health and psycho-social problems in older school age.

The need to initiate a thorough problem-solving of physical education of the youngest, was explicitly set by professional public of Germany (Brettschneider-Bredenbeck and Brandl 2008). Based on the research results related to insufficient physical activity and obesity in younger school children, German experts believe that the problem must be evaluated from the aspect of primary school teachers efficiency. Statements that future discussions on whether the health problems of offspring, resulting from insufficient activity and motor deficits, are more important than the pedagogical principles related to primary school teachers. Two options arose from the discussion about PE standards. The first option is focused on education through physical activity and sport, with the purpose of socialization and integration, stressing the psychological development of students. Another option insists on the educational goals through physical activities and sports, which are focused on physical development and the development of skills that are the basis of health. At this point it is not known which option shall prevail in the future. According to the forecasts of German experts, given the importance of physical education and sport in society, bearing in mind its social and medical role, regardless of pedagogical goal, the need shall prevail for public health. It will be the leading impetus for future development of physical and sports education.

Numerous authors in our country, based on the results of current researches, keep insisting on solving the problem of quality physical education in preschool and junior school age. Initial education of PE teachers, as well as their permanent education are such that allow much higher quality physical education for children and students at pre-school and junior school age than it is the case at the moment.

The significant resources that help understanding of the need to ensure quality education, correlation of the educational process goals with outcomes and standards, evaluation and self-evaluation at all levels, which among others helped formulation of 
this paper were: Ten Years of Compulsory Education Reforms (1984-1994) in some European countries (2001), Quality Education for All: Challenges of Education Reform in Serbia (2002), Quality Education for All: The Path to a Developed Society (2004); International Interdisciplinary Scientific Meeting: the European Dimension Of Education System Reform (2006) Europeanisation of Serbia (2007), Physical Education and Sport Education in European Union (2008), Draft Law on Basic Education (2009).

\section{ABOUT THE PE AIM AND STANDARDS IN PHYSICAL EDUCATION}

Although all the pedagogues of physical culture, all professional and scientific workers dealing with issues of school physical education, are familiar with the aim and tasks of physical education, this paper shall offer at least two reasons.

The first reason is related to the discussions and written materials about defining aim and tasks in educational subjects (educational areas), presenting critical evaluations, for example: „Declaratively expressed „educational goals" were so general and remote from real working conditions, the prescribed curriculum of vocational education and the harmonization of teachers, so they could represent a reference point in relation to which it would be possible to evaluate quality of the educational process and educational achievements on the level of the school network, particular school, certain curricula, teachers and students (Havelka et al. 2002, p. 153).

However, prior to such a negative general evaluation on the defining of aims and tasks in educational subjects, the Republic Commission for drafting a new curriculum and PE syllabus (1998-2000), already in 1999 formulated the general PE aim and general and specific operational tasks, with the explanation that ,... without a global aim, without theoretical guidelines, without the leading paradigm of global understanding of physical education in school and in social reality there is no valid basis for reform» (Bokan, 2003). Even then, the aim of physical education was focused on the construction of generative and transferable knowledge, skills and abilities:

„The PE aim is to contribute, with diverse and systematic motor activities associated with other educational areas, to the integral development of personality of students (cognitive, affective, motor), to development of motor skills, acquiring, development and implementation of motor skills, habits and necessary theoretical knowledge in everyday and specific conditions of life and work.

\section{General operational tasks:}

- Encouraging growth, development of students and influencing proper body posture;

- Development and improvement of motor abilities;

- Acquisition of motor skills, which are defined as the contents of PE curriculum and acquisition of theoretical knowledge required for their adoption;

- Acquiring of knowledge to understand the importance and essence of physical education, defined by the aim of this educational field;

- Formation of moral-willing personality qualities;

- Training students to use the acquired skills, knowledge and habits in everyday living and working conditions;

- Acquiring and developing awareness of the need for health, health care and protection of nature and the environment.

\section{Specific operational tasks:}

- Development of basic motor skills: speed, strength, endurance, flexibility and coordination

- Acquisition and development of motor skills and habits envisaged by PE syllabus;

- Application of the acquired knowledge, skills and habits in more complex conditions (through game, competition, etc.)

- Satisfying the social needs of approval, group identification, etc.;

- Aesthetic expression of movement and developments and experience of aesthetic values;

- The adoption of ethical values and encouraging feature of the willing students.

Another reason for stating the aims and tasks of physical education derives from their essential link with the outcomes and standards. The introductory part of the accepted Standards for completion of compulsory education states: „Between the standards, as set out in this document, and the aims listed in the curriculum, there are differences both in the function they have and the level of operationalization and accuracy of statements ,(Čarapić, G. U, 2009, p.5). The aim of physical education, as well as general and specific operational tasks are formulated to provide all the elements of quality outcomes and con- 
tain the predicted indicators of the recently accepted Standards for completion of compulsory education physical education. However, until the adoption of the Standards, there were no clear mechanisms for evaluation, especially in the part related to theoretical knowledge about physical training and physical education and evaluation of physical exercise and physical education by the students (certificate of values of physical exercises and physical education).

When it comes to the general and specific operational tasks, it can be concluded that they are formulated to cover functions, that physical education should have in the education system. The problems related to incorporating elements related to education through sport „Education through Sport” is still pending. Since the eighties, when the social functions of sport were emphasized, by the end of the nineties, when the educational function of sport was defined (Helsinki Report 1999 and Declaration - Nice 2000) and the declaration of 2004 as the ,year of education by sport", the non-formal education as factor of social integration has been recognized. The aforementioned analysis (Klein and Hardman 2008, p. 24) states as one of the essential objectives ,to develop co-operation between educational institutions and sports organizations to develop education by sport."

The processes which realize the functional relationship between, on one hand: subject: Physical education, mandatory elective subject: Physical education - selected sport, extracurricular activities and school sport (or sport in school?) and on the other side sports activities, in which a close link is created with the local community and sports clubs, are not simple nor can they be quickly achieved. The fact is that certain forms of these relations exist and that it is necessary to research and determine the quality of existing links. It is possible that the standards at the school level, their future clear requirements, in one of future changes, shall define the connection between school and sports, and thus to initiate significant changes in the field of ,education through sport.”

\section{THE EDUCATIONAL STANDARDS IN PHYSICAL EDUCATION FOR COMPLETION OF COMPULSORY EDUCATION}

The literature, which discusses the characteristics of standards in education, offers numerous formulations that describe them from different angles. The introductory part of the adopted national standards, provides general characteristics of the educational Standards for completion of compulsory education (Čarapić, G. U, 2009, p.5). The answers to the questions of how much the standards of physical education meet the features of general standards indicate the directions of activities inside and outside the profession. Therefore, general characteristics of the standards and comment on the possibility of their application within the standards of physical education, shall be given.

\section{Testability of specified educational outcomes}

\section{„Educational standards refer to the specific measurable, subject-specific knowledge, abilities and skills of students."}

For the subject Physical education, the educational standards are defined in three fields (RepicĆujić, V. et al. 2009):

COMPETENCE IN SKILLS (Sport games: basketball, volleyball handball, football; athletics: running, jumping, throwing; exercises on the floor and apparatus: floor, vault, beam, uneven bars, rings, pommel horse, horizontal bar, parallel bars; dancing; rhythmic gymnastics; table tennis and free exercise);

KNOWLEDGE OF PHYSICAL EXERCISE AND PHYSICAL EDUCATION (basic concepts of physical exercises and basic exercising rules, rules of sports games and individual sports, physical exercise impact on personality and the sense of Physical Education);

EVALUATION OF PHYSICAL EXERCISE AND PHYSICAL EDUCATION BY STUDENTS (beliefs, attitudes, interests, team work and self-actualization of students in physical exercise and physical activity in general and in the process of physical education in particular).

As specified in the series of notes within the standards, the field of "development of motor skills" is not specifically included in the standards. Teachers 
should refer to the existing texts published in the Official Gazette and Eurofit battery of tests. To change the standards, which will follow the application and research of the recently adopted standards, the profession is facing the formulation of indicators for the field of ,development and improvement of motor abilities", as well as the indicators that will determine the characteristics of students' body posture. These two fields have a significant place in the general operating tasks to achieve the aim and outcomes in physical education.

Anyway, fields, subfields and indicators, included in the standards in physical education, refer to the specific measurable, subject-specific, knowledge, skills and abilities of students, so that, with the amendments from the previous paragraph, they constitute a solid basis for quality evaluation in physical education classes.

\section{Focus on fundamental skills}

\section{„Educational standards concretize fundamental learning outcomes, structural knowledge of a field. They do not try to describe all the details and all variety of subject contents, but what is most important."}

During the adoption of the standard, there was a dilemma about whether to adopt the standards based on the curricula or the curricula should be adopted based on the standards. The Draft the Law on the Bases of Education System, Art. 72, para. 2 states: „The curriculum shall be adopted in accordance with the established principles, aims and standards of achievement", which solved the dilemma. However, when the standards are adopted for the first time, the initial basis results from a combination of what we have, i.e. the programs, and what we aim: outcomes and standards. It is significant that the standards have been adopted and that, in the process of their implementation on the basis of future research, they will be improved.

The members of the PE Working Group, based on research results used for adoption of the PE standards, taking as a starting point of the physical edu- cation syllabus, defined the most relevant contents: indicators of the adopted standards (except for indicators of position and development of students motor abilities and postural status). The final version of the standard is formulated in cooperation of expert consultants for individual fields and subfields, so it can be noted that, in this part, standards in physical education are focused on fundamental knowledge.

\section{Accumulation}

\section{„Educational standards take into account all relevant knowledge that students acquire in the course of education. Additionally, the highest levels of mastering include contents from the previous levels."}

PE educational standards have taken into account knowledge, students' skills and abilities skills during their studies. However, a number of competencies that a student should acquire in the first cycle of education, generally is not achieved, so that this, unfavorable situation reflects the quality of outcome at the end of compulsory education.

Legality of sensitive and critical periods of development of physical abilities and motor skills and abilities, especially from the area of coordination and speed, indicate that the failures in the work with the youngest, are very difficult, and often impossible, to compensate. Results of the research dealing with quality and efficiency of PE instruction at junior school age point to the serious consideration of these issues on a broader level (outside the close professional frames).

Teams with the coordinators of the Institute are preparing elaboration of proposals of educational standards for the completion of the first cycle of compulsory education of Serbian language, mathematics and nature and society. It would be of great importance that, in addition to these, standards for physical education be elaborated for the end of the first cycle of education. Namely, the standards, defined by the outcomes directly affect the curriculum, and the curriculum requires the competence of primary education teachers, for which there are limiting circumstances arising from the quality of initial education and interest in realization of PE instruction. 


\section{Differentiation}

\section{„Educational standards distinguish between different levels of achievement, according to the degree of realization of the competence they describe."}

Within the PE syllabus (content and method of achieving the syllabus), as well as at the initial training of PE teachers, there was always an attitude of appreciation of individual student's abilities and differentiation pursuant to their abilities: „In order to adjust the PE instruction to individual differences of the students, taken as a criterion in a differentiated approach, the teacher will direct each student or groups of students, to reduced or expanded contents, which are predicted by the curriculum in class, extra class and extracurricular organization of work (syllabus for the seventh grade, Official Gazette no.). From 1996 to 2000 the project, funded by the Ministry of Science and Technology, „Effects of differentiated $\mathrm{PE}$ instruction to psychosomatic status of children and youth" was realized in physical education, with the results of three published proceedings with 120 papers, which, among other things, indicates the importance given to respecting of the individual features of students.

The indicators describing the outcomes in Competences in skills are presented descriptively and in tables, through three levels of achievement, so that they comply with the requirement that implies differentiation as the standard feature.

\section{Understandability}

\section{„Educational standards are formulated in clear, concise and understandable terms to all participants in the education system."}

Educational standards in physical education are formulated so that they are understandable, especially to PE teachers. However, to make the students understand concepts and requirements that are described and formulated in the standards, teachers will have to devote, much more attention than ever, to theoretical education, which is interwoven in every PE class. The program contents of physical education are focused on theoretical education as well, which, if implemented, allow students to understand what, pursuant to the PE standards is expected from them. General operational tasks, inter alia, include: knowledge acquisition in order to understand the importance and essence of physical education; acquiring and developing awareness of the necessity of health, nature and environment protection; training students to use the acquired skills, knowledge and habits in everyday living and working conditions . Namely, the syllabuses for each grade state: „The implementation of the syllabus starts from the fact that PE aim cannot be achieved without active and conscious participation of students in educational and other forms of work."

\section{Feasibility}

\section{„Requirements that are defined within the standards are challenging for students and teachers, and can be achieved with adequate involvement."}

Members of the working group and consultants thought, based on the research carried out by the Working Group, as well as on other researches in physical education, that the requirements, defined within the standards, are feasible for the students in those schools with the existing material conditions for instruction realization of teaching. There are fields, such as swimming and floor and apparatus exercises, which are hard to give up in the process of physical education, but most often there are no more material conditions for their implementation. These are simultaneously the two subfields, whose results are best achieved at junior school age, in which physical education, not in the program scope and content, but in the concrete realization, for a variety of reasons, is the most disadvantaged position. Stressing that floor and apparatus exercises and swimming are particularly problematic for realization does not mean that space and equipment for other PE fields and subfields are provided in all schools. Outcomes, categorized into three groups according to the assignment difficulty for the subfields with provided conditions, are certainly challenging for students, teachers and school. However, it is a great challenge to ensure such working conditions so that the requirements defined within the standards can be achieved. 


\section{Compulsory for all}

\section{„Educational standards are applied to all students. (In working with special needs students a teacher should use his own professional experience when deciding which of the proposed standards can and should use)."}

The PE standards state that they do not cover by special needs students, or students who are partially exempt from certain activities for health reasons. In both cases, it is the teacher who checks standards in the field of competence in skills according to students' abilities. So the teacher uses not only his professional experience when deciding which of the proposed standards he can and should apply, but he solely creates indicators to adapt to special needs and students with health problems. Namely, the PE curriculum states that students with weak health, as well as the students who need corrective-pedagogical work (postural dysfunction), practice under a separate syllabus in regular classes at least once a week in classes of corrective-pedagogical work. The syllabus, which is suitable for students' health conditions is drafted by a teacher and physician-specialists. So practically, no students exempted from PE classes should exist, but their training should be adapted to individual abilities. These are the principles that have been long applied in physical education.. Adequate attention to students with special needs can be secured by high standards of security of the overall teaching process accompanied with additional professional training.

\section{REQUIREMENTS FOR MEETING THE PE STANDARDS AND CONTRIBUTION OF STANDARDS TO BETTER ORGANIZING INSIDE THE PROFESSION}

When considering the PE standards, we can identify the problems that we as a profession, have been putting on the agenda for decades and repeatedly but that have more or less successfully been exceeded. Solving these problems is of immediate importance for meeting the standards for completion of compulsory education. They can be classified into two subgroups: narrower and broader consideration context of the conditions for meeting the standards, having always in mind that solving these problems is to the benefit of students. Surely, the problems of subjective nature related to direct the work of teachers cannot be ignored. However, until there are limiting objective circumstances (space and equipment, work in junior primary school classes, standards related to the number of students in class, etc.) the problems of the subjective nature can be easily explained by them.

Future researches of PE standards should be conducted in schools that have adequate conditions for work and then conclude on the quality standards. It would be a step backwards, if we tried to adjust infinitely the standards, as well as physical education syllabuses on the national level with working conditions, primarily because the education outcomes should be adapted to students' abilities.

On this occasion we shall address, from NARROWER CONTEXT OF CONDITIONS FOR MEETING THE STANDARDS, school, local community, parents and PE teachers.

\section{Ensuring of school functions}

The first of two broader standard categories, recognized on the national level are „standards of input quality, material, technical, spatial conditions, the quality of teaching and other resources to ensure instruction realization „(Kovac-Cerović, T. et al. 2004, p. 64). Ensuring the standards of input quality to a large extent, is transferred to local community. However, without compliance with the criteria adopted on the national level and without their verification, the standards can hardly be achieved on broader level (all schools). „An institution can begin to work and to perform educational activities if it meets the prescribed requirements and possessed rooms, equipment and teaching aids (from the Law on the Bases of Education System, Art. 30, para. 3, item 1). Although, they do not depend only on school itself, in large number of schools, there are problems with material conditions for instruction realization (rooms and equipment). As in the PE syllabus, even in the standards, the instructions are prevailing, according to which, both should be implemented in accordance with the conditions. In no other educational field - subject, is there so much arbitrariness as in physical education. Up to the situation in which there are no conditions for instruction realization. Solving the problem of space and equipment in the school, for decades, has been linked to teacher's creativity and 
programming in accordance with the conditions. The category of teachers' creativity in physical education is as old as the educational curricula. However, when it comes to meeting the standards on the national lev$\mathrm{el}$, the profession may use them as a mechanism for providing adequate working conditions.

\section{Vertical correlation of implementing the aims and outcomes of the first and second cycle of compulsory education}

Providing of vertical connection of realization of aims and outcomes of the first cycle with the objectives and outcomes of the second cycle is a condition for meeting the standards for the completion of compulsory education. Realization of high quality physical education in junior classes, depends to a large extent on the working plan of the school (the Law on Basic Education: Autonomy of the institution, Art. 41; competence of management, Art. 57; Parents' Council, Art. 58; Competencies of professional bodies, teams and pedagogical collegiums, Art. 67; Educational work, Art. 87; Annual Working Plan, Art. 89; Students Parliament, Art. 105; Providing funds for higher quality teaching, Art. 160). The process of professional work very easily „moved” from the fourth grade, where subject teaching was applied in PE classes to the fifth. The examples of positive results in schools where subject $\mathrm{PE}$ teaching was implemented in the fourth, less frequently in the third grade, and sometimes even earlier, as well as the results of numerous studies conducted in the last ten years, master's theses and doctoral dissertations, speak in favor of serious consideration of a need of quality professional work with junior school age students on the national level. Advocating for this solution, our profession is keeping pace with the solutions proposed in the developed European countries.

\section{Ensuring of links between school and the local school community and parent involvement}

The constant insistence on resolving the problems that allow the realization of physical education in the scope and contents relevant for proper contribution to growth and integral development of students of all ages, cooperation is required between schools, local communities, parents and PE teachers. The local community has a number of legally established functions regarding the work of schools: the provi- sion of material conditions of work, the contents of certain parts of the curriculum (sports activities of interest to the local community as part of each grade), teacher training ... When it comes to physical education and sports activities, these functions are also achieved by cooperation with the municipal secretary for sport, who, among other things, deal with issues and organization of school sports competitions. A PE teacher is not alone any more and solely responsible for the realization of aims and outcomes of physical education: „Responsibility for the quality of education is not borne only by teachers, but also by all other stakeholders (parents and local community)," Kovac-Cerović, T. et al. 2004, p. 39.

The Ministry of Education works at implementation of the "Framework Action Plan for Protection of Children from Violence in Educational Institutions." By defining the third specific aim in this plan, the agenda for the local community states that it is responsible for providing preventive and protective role of school sport and sporting activities in the protection of children/students. Positive examples from practice, which are achieved with significant share of link between local communities and PE teachers already exist.

\section{Recruitment of teachers}

It is the teacher who is responsible for planning, programming and managing the process of teaching, monitoring and progress of students as well as for self-evaluation, whose results become the beginning of a new, corrected cycle planning. The Law on Basic Education, Art. 118 states: „The task of teachers is to ensure with their competences educational aims and standards of achievement, taking into account the principles of education, needs and interests and special abilities of a child or a student." Work planning in which there is a tendency to increase the quality of one's own work, is possible with the existence of indicators and standards, which concretize the teaching process aims and outcomes.

Quality initial education and professional training, ensure that a PE teacher assumes responsibility for the other two broad categories of standards, which is recognized on the national level (if the first one is fulfilled - author's comment), and these are: „Standards of quality outputs - the content and status, of knowledge, skills and abilities after comple- 
tion of schooling in general or of the specific level of schooling ,(Kovac-Cerović, T., et al. 2004, p. 64). When it comes to quality initial education one should be aware that none of the materials of the Ministry of Education and Sports, and today's the Ministry of Education, as well as in other materials related to education reform and teachers education, recognizes the Faculty of Sport and Physical Education as an institution whose programs, always were and still are, directed to the pedagogical and theoretical and methodological training of future teachers. This position stimulates the profession to engage in high-quality positioning within the education system.

FROM THE BROADER CONTEXT OF TERMS FOR MEETING STANDARDS, it is important, among other things, to bear in mind the process of implementation and improvement of standards on the national level and the role of professional and scientific workers in the scientific field of physical education and sport in that process. Application of the standards shall require a certain period of time for publication in the Official Gazette and informing the public that professional standards have been published, as well as for education of school counselors (supervisors...) and teachers. It is certain that, as it was with teacher training, there will be some difficulties in the beginning. However, when viewed in the overall context of powerful tools offered by the standards for assurance quality teaching process (the material conditions of work, objectives, outcomes, self-evaluation and external evaluation) other, important elements for improving the standards themselves can be expected.

In perspective, the standards shall include other, for physical education relevant, outcomes. For their formulation it will be necessary to realize numerous projects that are either directly related to standards, or directly affect the quality of the outcomes of physical education, for example:

\section{Definition of new indicators and standards}

It is important to include other relevant outcomes for physical education, such as position and development of motor abilities of students, characteristics postural status and characteristics of students' social behavior, which are directly related to the realization of PE process. The positive contribution of physical education can be achieved if we bear in mind an integral development of the child / student. The Standards for physical education for the completion of compulsory education, at any place where it is in context, note that it is necessary to conduct special research and propose tests for the national test battery. Working Group for drafting the standards did not have relevant data for this field, so the research shall follow, which can rely on numerous domestic and foreign experience.

\section{Creating a PE database}

Creating a PE database within a single information system of education is the next big project that will allow, with the parameters from the database and appropriate software, the students' results evaluation process, to formulate the criteria based on which the student refers to the physical and sporting activities in which he/she may have the most success, and thus self-evaluation and evaluation can become meaningful.

\section{Projects aimed at improvement of the standards and physical education syllabus.}

Realization of projects related to improving standards and physical education syllabus, basically depend on choice, quality and updating of the recorded parameters within a PE database within a single information system of education, which is, again, a separate project task. For these tasks, a cooperation would be beneficial between: the Institute for Quality Education, Institute for the Improvement of Education, Faculty of Sport and Physical Education ....

\section{Projects aimed at linking of physical education with other activities dealing with prevention, physical activities and sport}

In order to make physical education part of the overall process by which the physical education is offered to the community as an educational field of interest is necessary to further the realization of projects connected with the physical education programs: Strategy sport that deals with issues and education through sport and other issues related to the school and school sport; of the sport in which the mentioned 
school sports, personnel and physical infrastructure, from the documents that speak about the availability of physical activity and physical education to all students on equal terms, the Framework Action Plan for the protection of children from violence in education -educational institutions and numerous other documents that may be the basis for research projects.

\section{Projects that systematize and place in public the achieved results in the scientific field of Physical Education and Sport}

It would be particularly important to realize projects which would systematize significant results of previous research projects and papers, reached in the scientific field of physical education and sport, and that would be presented to the public, especially health care institutions, professional societies, pedagogues, psychologists, sociologists, educational and sporting institutions, as well as parliamentary bodies dealing with education.

\section{Project of promotion of work of the Association of physical education teachers}

Realization of the project aimed to improve work of the Society of physical education teachers and connection within this professional society, on which, after all, depends the realization of goals, outcomes, meeting the PE standards, and self-evaluation and evaluation would be an additional stimulus for better work in the PE education area (subject).

\section{CONCLUDING CONSIDERATIONS}

The standards provide significant support to efforts to ensure the quality of teaching and promote process of physical education: the material conditions of work, objectives, outcomes, and self-evaluation. They open the question of whether physical education should contain the education determinant in its name.

Standards inputs: material, technical, spatial conditions, the quality of teaching and other resources to ensure implementation of instruction, are important limiting factors for meeting the educational standards for the end of compulsory education.
General characteristics of the standards: differentiation, intelligibility, feasibility and compulsory for all, are fully applicable to the PE standards. When it comes to testability of specified educational outcomes and focus on fundamental knowledge it can be concluded that the fields and subfields, as well as indicators included in standards, refer to real measurable, subject-specific knowledge, skills and abilities of students. Clear mechanisms were established for evaluation, especially in the part that refers to the theoretical knowledge about physical training and physical education and evaluation of physical exercise and physical education by students (certificate of values of physical exercise and physical education). Due to inexistence of test battery accepted on the national level, characteristics of situation and development of motor abilities of students have not been taken into consideration, which is a serious flaw of the standards. Accumulation, as a general feature of the standards, is very problematic for PE. A series of competencies that a student should acquire in the first cycle of education, is generally not achieved, so that this, unfavorable situation reflects to the quality of the outcome at the end of compulsory education. Therefore, it would be of great importance to develop also a proposal for PE standards for the first cycle of education. Namely, the standards determined by outcomes directly affect the program, and the program requires the competence of primary education teachers. Limiting circumstances arising from the quality of initial homeroom teacher education, lack of working conditions and insufficient interest for the realization of physical education.

Provision of professional work in junior grades, to a large extent depends on the school, as it is left the possibility to initiate professional work depending on the work plan of the school. The Association of Physical Education Teachers should have its strategy of providing quality work with the youngest, having in mind the reference to the obligation to meet standards of education, as well as the fact that the responsibility for the quality of PE process is not borne only by teachers, but parents and local communities as well).

PE Teacher is responsible for quality standards of outputs - knowledge, skills and abilities after completion of schooling in general or of a specific level 
of schooling. This is enabled by high-quality initial education and training, and self-evaluation and evaluation.

In perspective, the standards will include other physical education relevant outcomes. Their formulation must be scientifically substantiated. Defining indicators and standards of the state and development of motor abilities of students, characteristics postural status and social behavior of students, which are directly related to the realization of the PE process requires the application of scientific research methodology.

Future research related to standards should be exercised in schools that have adequate material conditions for work and then make conclusions about their quality. It would be step backwards if we continued to try to harmonize standards and physical education curricula on the national level with the conditions. Such an approach does not lead to increase the PE quality. Students are capable of much better outcomes than those which are in present working conditions achieved, which adversely affects their integral development.

Formulated standards contribute, on one hand to motivation of every teacher, teachers' group, schools and local communities for high quality work, on the other hand, they motivate all stakeholders in the educational system to finally consider importance of physical activity and physical education for child / student. A series of research projects should be re-

\section{REFERENCES}

1. Bokan, B (2003). Elementi za raspravu o reformi fizičkog vaspitanja, Kebin, V. i ekspertski tim 1998-2000. (Elements for discussion on the reform of physical education. Kebin, V. and an expert team of 1998-2000) Expert opinion on the working material ,physical and health education". Letter to the heads of department for planning and programming for preschool and elementary education. Ministry of Education and Sports.

2. Brettschneider W-D., Brandl-Bredenbeck H.P. (2008). Physical education and education alized related to: creation of PE databases within a single information system of education, improving standards and physical education curriculum; linking of physical education with the activities of numerous institutions and the contents of documents that can be the basis for research projects; the project which would systematize significant results of research projects and papers in the scientific field of physical education and sport and presented them to the general public, promoting the work of the Association of Physical Education Teachers and connectivity within it ...

You must be aware of the fact that, very rarely, the materials of the Ministry of Education and Sports, today the Ministry of Education, as well as other materials related to education reform and teachers education, the Faculty of Sport and Physical Education are recognized as institutions whose programs have always been and still are, directed to the pedagogical and theoretical and methodological training of future teachers. This position initiates the profession to engage in high-quality positioning within the education system.

Standards in physical education are made. They appreciate the good elements of traditional values in our physical education and initiate, on one side contemporary processes of evaluation of outcomes, and on the other side, live activity within the profession and science of physical education and sport.

through sport in Germany. In Klein, G., Hardman, K., (eds) Physical Education and Sport Education in Europien Union. (pp. 145-161). Paris: Edition Revue EP.S.

3. Eurydice: Information network of educational systems in Europe (1996). Ten years of compulsory education reforms (1984-1994) in some European countries. Translated from German by Thomas, S. (2001). Belgrade: Ministry of Education and Sports Republic of Serbia Law on Bases of Educational System, Official Gazette of the Republic of Serbia 72/2009. 
4. Havelka, N., Baucal, A., D. Plut., Matovic, N., Pavlovic Babic, D. (2002). Sistem za praćenje i vrednovanje kvaliteta obrazovanja. Predolog promena i inovacija (2002-2005) (System for monitoring and evaluating the quality of education. Proposed changes and innovations (20022005). In T. Kovač-Cerović, Lj. Levkov (Eds.). Quality Education for All: The way to a developed society (pp. 149-205). Belgrade: Ministry of Education and Sports Republic of Serbia.

5. Jelinčić, J., Lukšić-Orlandić, T., Đurović, S. (2007). Evropeizacija Srbije (Europeanisation of Serbia). Belgrade: Fund for Open Society.

6. Kamenov, E. (2006). Poruke i zaključci naučnog skupa "Evropske dimenzije reforme sistema obrazovanja i vaspitanja". (Messages and conclusions of the Symposium „European dimension of education system reform and education"). U E. Kamenov (Ed.). Conference Proceedings. International interdisciplinary scientific meeting: European Dimensions of Educational System Reform. (pp. 5-12). Novi Sad: Faculty of Philosophy, Department of Pedagogy

7. Klein, G., Hardman, K., Coord. (2008). Physical Education and Sport Education in Europien Union. Paris: Edition Revue EP.S,

8. Kovač-Cerović, T., Grahovac, V, Stanković, D., Vuković, N., Ignjatović, S., Šćepanović, D. i sar. (2004). Kvalitetno obrazovanje za sve: Izazovi reformi obrazovanja u Srbiji. (Quality education for all: Challenges of educational reform in Serbia). Belgrade: Ministry of Education and Sports Republic of Serbia.
9. Law on Basic Education System, Official Gazette of Republic Serbia 72/2009.

10. Ministry of Education of the Republic of Serbia (2008): Framework Action Plan for the Prevention of Violence in Educational Institutions, Belgrade

11. Regulation on the curriculum for seventh grade of elementary education. Educational Gazette of the Republic of Serbia, 6/2009.

12. Radovanovic, Đ., Project manager (1996-2000). Efekti diferencirane nastave fizickog vaspitanja na psihosomatski status dece i omladine (Effects of differentiated PE teaching to psychosomatic status of children and youth). Ministry of Science and Technology of Serbia. University of Novi Sad, Faculty of Physical Education

13. Repić Ćujić, V., Gortnar, Z., Višnjić, D., Radisavljević, S., Lepeš, J., i Zečević, S. (2009). Obrazovni standardi za kraj obaveznog obrazovanja, Fizičko vaspitanje. (Educational standards for completion of compulsory education, physical education). Belgrade: Ministry of Education of the Republic of Serbia, Institute for Evaluation of Educational Quality (www.ceo. edu.rs)

14. Čarapić, G.U. (2009). Obrazovni standardi za kraj obaveznog obrazovanja (Educational standards for completion of compulsory education). Belgrade: Ministry of Education and Sports Republic of Serbia, Institute for Evaluation of Educational Quality (www.ceo.edu.rs) 


\title{
СТАНДАРДИ У ФУНКЦИЈИ УНАПРЕЪИВАҢА КВАЛИТЕТА ФИЗИЧКОГ ВАСПИТАЫА
}

\begin{abstract}
Сажетак
У оквиру Стандарда за крај обавезног образовања, које је израдио Завод за вредновање квалитета образовања и васпитања, а 19.05.2009. године донео Национални просветни савет Србије, налазе се стандарди за десет наставних предмета, међу којима је и предмет физичко васпитање. Циљ овог рада је да се, непосредно после доношења стандарда, а могућно је и пре њиховог објављивања у Службеном гласнику, стручна јавност упозна, припреми и активира за процес њиховог уграђивања и примену у праксу. У раду се разматрају основне карактеристике стандарда за физичко васпитање: проверљивост; усмереност на темељна знања, умења и вештине; кумулативност (узимајући у обзир садржаје оба циклуса основног образовања); диференциран приступ ученицима; разумљивост; изводљивост и обавезност. Упоредном анализом формулисаног, важећег, циља физичког васпитања, програма физичког васпитања за основно образовање и препорука за начин његовог остваривања и карактеристика образовних стандарда за крај основног образовања, у којима се образовни циљеви и задаци конкретизују кроз постигнућа ученика - исходе видљиве у понашању и расуђивању, одговара се на питање како се могу постићи бољи ефекти, повећати квалитет физичког васпитања, са капацитетима, којима располажемо. Усмерени на: оспособљеност у вештинама; знања о физичком вежбању и физичком васпитању и вредновање физичког вежбања и физичког васпитања од стране ученика, стандарди објективизују оцењивање и оцене чине упоредивим и дају основу за даље развијање инструмената за самовредновање. Један од значајних доприноса остваривања наставног процеса у складу са образовним стандардима је активирање наставника, ученика, родитеља и школе. У раду се постављају и дилеме у вези са конкретним проблемима у васпитно-образовној области (предмету) физичко васпитање, пре свега условима за реализовање програма физичког васпитања, као и реализовање наставних садржаја, у оквиру првог циклуса основног образовања, које се директно рефлектују на могућност достизања стандарда за крај обавезног образовања. У вези са тим наглашава се потреба да се донесу и стандарди и обезбеди њихова пуна реализација на крају првог циклуса основног образовања.
\end{abstract}

КљУчне речи: ЗАВРШЕТАК ОБАВЕЗНОГ ОБРАЗОВАЊА / ОБРАЗОВНИ ПРОЦЕС / ОСПОСОБљЕНОСТ / ВЕШТИНЕ / ЗНАњА

\section{УВОД}

У оквиру Стандарда за крај обавезног образовања, које је израдио Завод за вредновање квалитета образовања и васпитања, а 19.05.2009. године донео Национални просветни савет Србије, налазе се стандарди за десет наставних предмета, међу којима је и предмет Физичко васпитање. Циљ овог рада је да се, непосредно после доношења стандарда, а могућно је и пре њиховог објављивања у Службеном гласнику, стручна јавност упозна, припреми и активира за процес њиховог уграђивања и примену, као и да се истакну значајне могућности везане за побољшање стања и функционисања битних сегмената за физичко васпитање. У публикацији „Обавезни стандарди за крај обавезног образовања“, станадарди се дефинишу 
као: „... искази о темељним знањима, вештинама и умењима које ученици треба да стекну до одређеног нивоа образовања. Стандарди артикулишу најважније захтеве школског учења и наставе и исказују их као исходе видљиве у понашању и расуђивању ученика“ (Чарапић, 2009., стр.5).

Као инструменти укупног образовног процеса стандарди се баве његовим најосетљивијим делом - исходима и постају део механизма осигурања квалитета. Образовни стандарди за крај обавезног образовања имају карактер завршног вредновања. Међутим, у Закону о основама система образовања и васпитања предвиђени су посебни страндарди постигнућа, који се утврђују према узрасту, разредима, предметима, односно модулима на основу општих исхода образовања и васпитања и општих стандарда постигнућа (члан 5, став 6). За физичко васпитање би било значајно формулисање процесних стандарда као дела вредновања које се врши раније и пружа могућност утицаја на даљи ток образовног процеса.

У физичком васпитању се често доносе паушални и научно неутемељени судови, од крајње негативних оцена материјалних услова рада, рада наставника и садржаја програма, преко констатација да нам је физичко васпитање онакво какво нам је образовање уопште, па до позитивних оцена, које се заснивају на добрим примерима из праксе. Ми и не знамо поуздано какво је реално стање и која од поменутих карактеристика наставе физичког васпитања преовладава.

Иако су постојали, а и данас у физичком васпитању постоје, критеријуми на основу којих се процењују успех ученика, наставника и школе, до сада није постојао систематски и, на основу општеприхваћених стандарда утемељен процес вредновања исхода после одређеног степена школовања и то на релацији: циљ, задаци, исходи и стандарди. Због тога није било могућно вршити објективније самовредновање, као ни упоређивање властитих резултата рада са резултатима других, на нивоу школе, локалне самоуправе или на ширем, националном плану. Применом националних стандарда ови процеси ће бити могућни. Међутим, треба имати у виду да, када је физичко васпитање у питању, испуњавање стандарда зависи од низа чинилаца који диктирају прилагођавања и, у великом броју школа, умањују могућности њиховог остваривања.
Потреба успостављања евалуације образовног процеса и у оквиру тога и физичког (спортског) образовања и васпитања, у смислу у ком га данас тумачимо, дефинисана је у анализи објављеној 1996. године (пре више од десет година, а односи се на период од десет година који је претходио објављивању): „Десет година реформи обавезног образовања у (1984-1994) у неким европским земљама“ (Eurydice, 1996). Тада се описују појмови: стратегија мишљења и решавања проблема, као и технике комуницирања (Луксембург), стратегија учења (Шпанија, Италија, Холандија), вођење рачуна о индивидуалним потребама (Велика Британија), и развоју индивидуе у њеној целовитости (Данска), усмеравање тежишта према осећању добробити и пријатности (Аустрија, Француска, Белгија). У периоду од 1984-1994., као претече исхода, у физичком васпитању појављују се минимални образовни захтеви. И у нашим програмима физичког васпитања још од 1984. године, за сваку подобласт, као саставни део програмских целина, по разредима, дефинисани су и минимални образовни захтеви, што указује да је струка, пратила процесе у физичком васпитању изван нашег простора.

У закључцима бројних истраживања, теоријских и стручних расправа крајем прошлог и почетком овог века, разматрани су проблеми физичког васпитања у школи. На највишим телима Европске Уније (Савет Европе), конференацијама везаним за велике спортске догађаје, европским, регионалним и националним политичким и научним скуповима, установљена је „криза физичког васпитања“ и предлагана су различита решења, од којих су нека била примењивана у пракси, а нека су остала на нивоу теоријске расправе. То је био период живих активности, док је у нашој земљи, из низа објективних али и других разлога, дошло до стагнације или опадања материјалне основе и квалитета наставног процеса у физичком васпитању.

Новији извештаји о организацији и стању у физичком васпитању са једне и у систему спорта са друге стране у 26 европских земаља, као и детаљна анализа урађена на основу њих (Klein, \& Hardman, 2008) показују различит положај и дефинисање циља физичког васпитања у оквиру националних курикулума. Извештаји и анализа, 
који паралелно са разматрањем положаја, циља и задатака физичког васпитања разматрају и елементе организације спорта, као и везе између система образовања и система спорта, показују да, уз одређене разлике, постоји велики број проблема, које препознајемо и у нашој земљи. Међутим, са три часа физичког васпитања у првом циклусу образовања и три часа у другом циклусу (два часа физичког васпитања и један час обавезног изборног предмета: Физичко васпитање - Изабрани спорт), ванчасовним активностима и школским спортом, може се рећи да је физичко васпитање, тренутно, добро позиционирано у образовном систему, те да је ову позицију потребно бранити, задржати и уложити много енергије да физичко васпитање буде квалитетније. Данас, у програму за старије разреде основне школе постоји један час (трећи у недељном фонду) Физичко васпитање - изабрани спорт, као обавезни изборни предмет. Међутим, не значи да ће тако и остати. Унапред би требало предвидети и супроставити се могућној промени, која се, на пример, догодила у Словенији:

„We (teachers and pupils) lost 1 lesson per week in higher grades (7-9), they have only 2 „, hours“ per week. I think that is not good idea, because pupils have more and more health problems and weight problems is becoming bigger problem also; facilites: some schools have really old and bad sport halls and equipment; that is not enough for quality teaching, so pupils in those schools may lack possibility of large sport knowledge; pupils don't like sport anymore, they rather decide to stay at home and work and play computers; that's why teaching is becoming harder and pupils physical fitness dropping rapidly; more and more pupils have some kind of disability, teachers have to deal with those problems on their own“. (Klein, \& Hardman, 2008., стр 14).

Толико пута, у различитим формулацијама, поновљена констатација да савремен начин живота доноси недовољно кретање и последице: гојазност, поремећаји у држању тела, јувенилни дијабетес и кардиоваскуларна обољења, дакле све хронична незаразна обољења, као и психосоцијалне проблеме, била би злоупотребљена да није „болно“ тачна, и да се не генерише већ у млађем школском узрасту.
Због чега говоримо о свим овим проблемима у уводном разматрању о Стандардима у физичком васпитању на крају обавезног образовања? Због тога што процес физичког васпитања, исходи и стандарди тешко да могу бити остварени уколико не постоји вертикална повезаност наставних садржаја и исхода, најмање по циклусима. За физичко васпитање је, често недовољно или „никакво“ реализовање програма у првом циклусу образовања - уз изузетке, одувек (60 година) био проблем који је у старијим разредима другом циклусу, готово немогуће превазићи. Као и за друге образовно-васпитне области, и за физичко васпитање је рад у млађем школском узрасту од непроцењиве важности. Могућно је да би квалитетно физичко васпитање у млађем узрасту, утицало на стварање навике и потребе ученика за телесним вежбањем, па се не би, у толикој мери, исказивали разновврсни здравствени и психосоцијални проблеми у старијем школском узрасту.

Потребу да се приступи темељитом решавању проблема физичког образовања и васпитања најмлађих, експлицитно је поставила стручна јавност Немачке (Brettschneider \& Brandl-Bredenbeck 2008). На основу резултата истраживања везаних за недовољну физичку активност и гојазност деце млађег школског узраста, немачки стручњаци сматрају да проблем мора бити евалуиран с аспекта ефикасности рада наставника разредне наставе. Наводе да будућа дискусија о томе да ли здравствени проблеми потомства, који ће бити последица недовољне активности и моторичког дефицита, имају већи значај од педагошког принципа везаног за наставника разредне наставе. У дискусија о стандардима у физичком васпитању издвојиле су се две опције. Прва опиија је усмерена на васпитање путем физичке активности и спорта, чија је сврха социјализација и интеграција са истицањем подршке психолошком развоју ученика. Друга опичја инсистира на циљевима образовања и васпитања путем физичке активности и спорта, који су фокусирани на физички развој и развој способности које су у основама здравља. У овом тренутку се не зна која ће опција преовладати у будућности. Према прогнози немачких стручњака, с обзиром на значај физичког васпитања и спорта у друштву, имајући у виду његову социјалну и здравствену 
улогу, без обзира на педагошки циљ, преовладаће потреба за јавним здрављем. Она ће бити водећи подстицај за будући развој физичког и спортског образовања и васпитања.

Бројни аутори у нашој земљи, на основу резултата актуелних истраживања, све више инсистирају на решавању проблема квалитетног физичког васпитања у предшколском и млађем школском узрасту. Иницијално образовања професора физичког васпитања, као и њихово перманентно образовање су такви да омогућавају знатно квалитетније физичко васпитање деце и ученика предшколског и млађег школског узраста него што је то данас случај.

Значајни извори који помажу разумевању потребе осигурања квалитета образовања, повезаности циљева образовног процеса, исхода и стандарда, вредновања и самовредновања на свим нивоима који су, између осталих, помогли у формулисању овог рада били су: Десет година реформи обавезног образовања (1984-1994) у неким европским земљама (2001); Квалитетно образовање за све: Изазови реформи образовања у Србији (2002); Квалитетно образовање за све: Пут ка развијеном друштву (2004); Међународни интердисциплинарни научни скуп: Европске димензије реформе система образовања (2006); Европеизација Србије (2007), Physical Education and Sport Education in Europien Union (2008), Предлог Закона о основама система образовања и васпитања (2009).

\section{О ЦИљУ ФИЗИЧКОГ ВАСПИТАҢА И СТАНДАРДИМА У ФИЗИЧКОМ ВАСПИТАњУ}

Иако су свим педагозима физичке културе, свим стручним и научним радницима који се баве питањима школског физичког васпитања, циљ и задаци физичког васпитања познати, у овом раду они ће се навести се из најмање два разлога.

Први разлог је везан за расправе и писане материјале о дефинисању циља и задатака у образовним предметима (образовно-васпитним областима), којима се исказују критичке оцене, на пример: «Декларативно изношени «васпитнообразовни циљеви» били су толико уопштени и удаљени од реалних услова рада, прописаног на- ставног плана и програма стручног образовања и усаглашавања наставника, да нису могли представљати референтну тачку у односу на коју би било могуће вредновати квалитет образовног процеса и образовних постигнућа на нивоу школске мреже, конкретне школе, појединих наставних програма, наставника и ученика (Хавелка и сар. 2002., стр. 153).

Међутим, пре овакве негативне опште оцене о дефинисању циља и задатака у образовним предметима, Републичка комисија за израду новог наставног плана и програма физичког васпитања (1998-2000), још 1999. године формулисала је општи циљ физичког васпитања, као и опште и посебне оперативне задатке, са образложењем да «...без глобалног циља, без теоријске одреднице, без водеће парадигме о глобалном поимању физичког васпитања у школској и друштвеној стварности нема ваљаног основа за реформу» (Бокан, 2003). Већ тада је циљ физичког васпитања био усмерен на изградњу генеративних и трансферних знања, вештина и умења:

„Циљ наставе физичког васпитања јесте да разноврсним и систематским моторичким активностима, повезаним са осталим васпитнообразовним подручјима, допринесе интегралном развоју личности ученика (когнитивном, афективном, моторичком), развоју моторичких способности, стицању, усавршавању и примени моторичких умења, навика и неопходних теоријских знања у свакодневним и специфичним условима живота и рада“.

\section{Општи оперативни задаци:}

- подстицање раста, развоја ученика и утицање на правилно држање тела;

- развој и усавршавање моторичких способности;

- стицање моторичких умења која су као садржаји утврђени програмом физичког васпитања и стицање теоријских знања неопходних за њихово усвајање;

- усвајање знања ради разумевања значаја и суштине физичког васпитања, дефинисаног циљем овог васпитно-образовног подручја;

- формирање морално-вољних квалитета личности;

- оспособљавање ученика да стечена умења, знања и навике користе у свакодневним условима живота и рада; 
- стицање и развијање свести о потреби здравља, чувања здравља и заштити природе и човекове средине.

\section{Посебни оперативни задаци:}

- развој основних моторичких способности: брзине, снаге, издржљивости, гипкости и координације

- стицање и усавршавање моторичких умења и навика предвиђених програмом физичког васпитања;

- примена стечених знања, умења и навика у сложенијим условима (кроз игру, такмичење и сл.);

- задовољавање социјалних потреба за потврђивањем, групним поистовећивањем и сл;

- естетско изражавање покретом и кретањима и доживљавање естетских вредности;

- усвајање етичких вредности и подстицање вољних особина ученика.

Други разлог за навођење циља и задатака физичког васпитања произилази из њихове суштинске везе са исходима и стандардима. У уводном делу прихваћених Стандарда за крај обавезног образовања стоји: „Између стандарда, како су у овом документу постављени, и циљева наведених у наставним програмима постоје разлике, како у функцији коју имају тако и у степену операционализације и прецизности исказа“ (Чарапић, 2009., стр.5). Циљ физичког васпитања, као и општи и посебни оперативни задаци формулисани су тако да пружају све елементе за квалитетне исходе и садрже предвиђене индикаторе недавно прихваћених Стандарда за крај обавезног образовања - физичко васпитање. Међутим, до доношења Стандарда нису постојали јасни механизми за вредновање, посебно у делу који се односи на теорјска знања о физичком вежбању и физичком васпитању и вредновању физичког вежбања и физичког васпитања од стране ученика (уверење о вредностима физичког вежбања и физичког васпитања).

Када је реч о циљу и општим и посебним оперативним задацима, може се констатовати да су они формулисани тако да покривају фукције, које би физичко васпитање у систему образовања требало да има. Предстоји разматрање проблема везаних за уграђивање елемената који се односе на образовање и васпитање путем спорта „Education through sport“. Од осамдесетих година, када се истичу социјалне функције спорта, до краја деведесетих, када се дефинише образовно-васпитна функција спорта (Хелсиншки извештај 1999. и Декларација Ница 2000) и проглашавања 2004. године као „године васпитања спортом“, види се препознавање неформалног образовања и васпитања и као фактора социјалне интеграције. У поменутој анализи (Klein, \& Hardman, 2008., str. 24). као један од суштинских циљева наводи се: „to develop cooperation between educational institutions and sports organizations to develop education by sport“.

Процеси којима се остварује функционална веза између, са једне стране: предмета Физичко васпитање, Обавезног изборног предмета: Физичко васпитање - Изабрани спорт, ванчасовних активности и школског спорта (или спорта у школи?) и, са друге стране спортских активности, у којима се ствара блиска веза са локалном заједницом и спортским клубовима, нису једноставни нити се могу брзо остварити. Чињеница је да одређене форме ових веза постоје и да је потребно истражити и установити квалитет постојећих веза. Могућно је да ће стандарди на нивоу школе, својим будућим јасним захтевима, у некој од наредних промена, дефинисати везу између школе и спорта, и на тај начин иницирати значајне промене на пољу „васпитања путем спорта“.

\section{О ОБРАЗОВНИМ СТАНДАРДИМА У ФИЗИЧКОМ ВАСПИТАҢУ ЗА КРАЈ ОБАВЕЗНОГ ОБРАЗОВАЫА}

У литератури, у којој се разматрају карактеристике стандарда у образовању, постоје бројне формулације које их описују из различитих углова. У уводном делу донетих националних стандарда, наведене су опште карактеристике Образовних стандарда за крај обавезног образовања (Чарапић, 2009., стр.5).. Одговори на питања колико стандарди из физичког васпитања задовољавају карактеристике општих стандара упућују на правце деловања унутар и изван струке. Због тога ће се навести опште карактеристике стандарда и коментар о могућностима њихове примене у оквиру стандарда из физичког васпитања . 
Радојевић Ј., Стандарди у функцији унапређивања квалитета... ФИЗИЧКА КУЛТУРА 2011; 65 (1): $70-83$

\section{1. Проверљивост спецификованих образовних исхода}

«Образовни стандарди се односе на конкретна мерљива, за предмет специфична, знаьа, умења и вештине ученика."

За предмет Физичко васпитање образовни стандарди су дефинисани у три области (РепићЋујић, и сар. 2009):

ОСПОСОБЉЕНОСТ У ВЕШТИНАМА (Спортске игре: кошарка, одбојка рукомет, фудбал; Атлетика: трчање, скокови, бацање; Вежбе на справама и тлу: тло, прескок, греда, двовисински разбој, кругови, коњ са хватаљкама, вратило, разбој; Плес; Ритмичка гимнастика; Стони тенис и Вежбе обликовања);

ЗНАЊА О ФИЗИЧКОМ ВЕЖБАЊУ И ФИЗИЧКОМ ВАСПИТАњУ (основни Појмови о физичком вежбању и основна правила вежбања, правила спортских игара и индивидуалних спортова, утицај физичког вежбања на личност, као и смисао Физичког васпитања);

ВРЕДНОВАЊЕ ФИЗИЧКОГ ВЕЖБАҢА И ФИЗИЧКОГ ВАСПИТАҢА ОД СТРАНЕ УЧЕникА (уверења, ставови, интересовања, тимски рад и самоактуализација ученика у физичком вежбању и физичком активностима уопште и процесу физичког васпитања посебно).

Као што је у низу напомена у оквиру стандарда наведено, област „развој моторичких способности“ није посебно обухваћена стандардима. Наставници се упућују на постојеће тестове објављене у Службеном гласнику и Еурофит батерију тестова. За промену стандарда, која ће уследити након примене и истраживања недавно донетих стандарда, струци предстоји формулисање индикатора за област „развој и усавршавање моторичких способности“, као и индикатора којима ће се установити карактеристике држања тела ученика. Ове две области имају значајно место у општим оперативним задацима којима се постижу циљ и исходи у физичком васпитању.

Иначе, области, подобласти и индикатори, који су стандардима из физичког васпитања обухваћени, односе се на конкретна мерљива, за предмет специфична, знања, умења и вештине ученика. тако да, уз допуну из претходног става, представљају солидну основу за вредновање квалитета у предмету Физичко васпитање.

\section{2. Фокус на темељна знања}

«Образовни стандарди конкретизују темељне исходе учења, структурна знања из неке области. Они не покушавају да опишу све детаље и сву разноликост предметног садржсаја, већ оно ито је најбитније.

Приликом доношења стандарда постојала је дилема о томе да ли се стандарди доносе на основу наставних програма или се наставни програми доносе на основу стандарда. У Предлогу Закона о основама система образовања и васпитања, члану 72 стоји, став 2: „Наставни план и програм доноси се у складу са утврђеним принципима, циљевима и стандардима постигнућа“, чиме се дилема разрешава. Међутим, када се стандарди први пут доносе, почетна основа произилази из комбинације онога што имамо, а то су програми и онога што нам је циљ: исходи и стандарди. Значајно је да су стандарди донети и да ће, у процесу њихове примене и на основу будућих истраживања бити усавршавани.

Чланови Радне групе за физичко васпитање су, на основу резултата истраживања на основу кога су стандадри за физичко васпитањи донети, имајући као полазну основу програм физичког васпитања, дефинисали најбитније садржаје: индикаторе за донете стандарде (осим за показатеље стања и развоја моторичких способности ученика и постуралног статуса). Коначна верзија стандарда формулисана је уз сарадњу стручних консултаната за поједине области и подобласти, тако да се може констатовати да су, у том делу, стандарди у физичком васпитању фокусирани на темељна знања.

\section{3. Кумулативност}

«Образовни стандарди узимају у обзир сва битна знања која ученик стиче током иколоваьа. Такође највиши нивои знава подразумевају овладаност садржајима са претходних нивоа."

Образовни стандарди из физичког васпитања јесу узели у обзир знања, умења и вештине која ученик стиче током школовања. Међутим, низ компетенција које је ученик требало да стекне у првом циклусу образовања, углавном није остварен, тако да се ово, неповољно, стање 
рефлектује на квалитет исхода на крају обавезног образовања.

Законитости сензитивних и критичних периода развоја физичких способности и моторичких умења и вешитина, посебно из простора координације и брзине, указују да се пропуштено у раду са најмлађим касније, тешко, а често и никако не може надокнадити. Резултати истраживања која су се бавила квалитетом и ефикасношћу наставе физичког васпитања у млађем школском узрасту упућују на озбиљно разматрање ових проблема на ширем плану (изван оквира уже струке).

Тимови са координаторима Завода припремају израду предлога образовних стандарда за крај првог циклуса обавезног образовања из Српског језика, Математике и Природе и друштва. Било би од изузетне важности да се, поред наведених, за крај првог циклуса образовања, изради и предлог стандарда из Физичког васпитања. Наиме, стандарди, одређени исходима непосредно утичу на програм, а програм захтева компетенције наставника разредне наставе, за које постоје ограничавајуће околности које проистичу из квалитета иницијалног образовања и интересовања за реализовање наставе физичког васпитања.

\section{4. Диференцијација}

\section{«Образовни стандарди праве разлику између различитих нивоа постигнућа, према степену оствариваьа компетенције коју описују.«}

У програму физичког васпитања (садржај и начин остваривања програма), као и на иницијалном оспособљавању професора физичког васпитања, увек је постојао став о уважавању индивидуалних способности ученика и диференцијацији према њиховим способностима: „Да би настава физичког васпитања била примерена индивидуалним разликама ученика, који се узимају као критеријум у диференцираном приступу, наставник ће сваког ученика или групе ученика, усмеравати на смањене или проширене садржаје, који су предвиђени наставним планом и програмом, у часовној ванчасовној и ваншколској организацији рада (програм за седми разред, Службени гласник бр. ). У физичком васпитању је, од 1996 до 2000. године реализо- ван пројекат „Ефекти диференциране наставе физичког васпитања на психосоматски статус деце и омладине“, који је финансирало Министарство за науку и технологију, из кога су објављена три зборника радова са 120 радова што, између осталог, указује на значај који струка придаје уважавању индивидуалних карактеристика ученика.

Индикатори који описују исходе у Оспособљености у вештинама приказани су описно и табеларно, кроз три нивоа постигнућа, тако да су у складу са захтевом који подразумева диференцијацију као карактеристику стандарда.

\section{5. Разумьивост}

\section{«Образовни стандарди су формулисани јасно, концизно и помоћу појмова разумливих за све учеснике у систему образоваьа.«}

Образовни стандарди из физичког васпитања формулисани су тако да су разумљиви, пре свега за наставнике физичког васпитања. Међутим, како би ученици разумели појмове и захтеве који су у стандардима описани и формулисани, наставници ће морати, знатно већу пажњу него до сада, да посвете теоријском образовању које је уткано у сваки час физичког васпитања. Програмски садржаји физичког васпитања усмерени су и на теоријско образовање, које, уколико се реализује, ученицима омогућава да схвате шта је то што се, на основу стандарда у физичком васпитању од њих очекује. Општи оперативни задаци, између осталог, обухватају: усвајање знања ради разумевања значаја и суштине физичког васпитања; стицање и развијање свести о потреби чувања здравља и заштити природе и човекове средине; оспособљавање ученика да стечена умења, знања и навике користе у свакодневним условима живота и рада. Наиме, у програму за сваки разред стоји: »У реализацији програма полази се од чињенице да се циљ наставе физичког васпитања не може остварити без активног и свесног учешћа ученика у наставним и другим облицима рада.» 


\section{6. Изводљивост}

«Захтеви који су дефинисани унутар стандарда представљају изазов за ученике и наставнике, а могу бити остварени уз адекватно ангажовање."

Чланови радне групе и консултанти су, на основу истраживања које је Радна група спровела, као и на основу других истраживања у физичком васпитању, сматрали да су захтеви који су дефинисани унутар стандарда изводљиви за ученике у оним школама у којима постоје материјални услови за реализовање наставе. Постоје подобласти, као што су Пливање и Вежбе на справама и тлу, од којих је, у процесу физичког васпитања тешко одустати, а за које, најчешће више не постоје материјални услови за реализацију. Ово су истовремено и две подобласти, чији се резултати најквалитетније постижу у млађем школском узрасту, у коме је физичко васпитање, не у програмском обиму и садржају, већ у конкретној реализацији, из низа разлога, у најнеповољнијем положају. То што се Вежбе на справама и тлу и пливање наводе као посебно проблематични за реализовање, не значи да су простор и опрема за друге области и подобласти физичког васпитања, у свим школама, обезбеђени. Исходи, сврстани у три групе према тежини задатака за подобласти за које постоје услови, свакако представљају изазов за ученике, наставнике и школу. Међутим, велики је изазов обезбедити такве услове рада да се, захтеви дефинисани унутар стандарда, могу остварити.

\section{7. Обавезност за све}

«Образовни стандарди се примењују на све ученике. (У раду са ученицима са посебним потребама наставник треба да користи своје професионално искуство када одлучује које од предложених стандарда може и треба да примени)."

У стандардима за физичко васпитање стоји да стандардима нису обухваћени ученици са посебним потребама, као ни ученици који су делимично ослобођени појединих активности из здравствених разлога. У оба случаја наставник врши проверу стандарда у области Оспособљеност у вештинама према могућностима ученика. Дакле наставник не само да користи своје професионално искуство када одлучује које од предложених стандарда може и треба да примени, већ и сам креира индикаторе које прилагођава ученицима са посебним потребама и здравственим проблемима. Наиме, у програму физичког васпитања стоји да ученици ослабљеног здравља, као и ученици, којима је потребан корективно-педагошки рад (постурални поремећаји), вежбају према посебном програму на редовним часовима и најмање једанпут недељно на часовима корективно-педагошког рада. Програм, који је примерен здравственом стању ученика, сачињавају наставник и лекарспецијалиста. На тај начин практично не би требало да има ученика који су ослобођени наставе физичког васпитања, већ се њихово вежбање прилагођава индивидуалним могућностима. Ово су принципи који се у физичком васпитању одавно примењују. Адекватна пажња ученицима са посебним потребама може се посветити уз високе стандарде обезбеђења укупног наставног процеса и уз додатно професионално оспособљавање.

\section{УСЛОВИ ЗА ИСПУЫАВАЫЕ СТАНДАРДА У ФИЗИЧКОМ ВАСПИТАНУ И ДОПРИНОС СТАНДАРДА БОЉЕМ ОРГАНИЗОВАњУ УНУТАР СТРУКЕ}

Приликом разматрања стандарда у физичком васпитању идентификују се проблеми које смо, као струка, деценијама и у више наврата постављали на дневни ред и, са мање или више успеха, превазилазили. Решавање ових проблема је од непосредног значаја за испуњавање стандарда за крај обавезног образовања. Могу се сврстати у две подгрупе: ужи и шири контекст разматрања услова за испуњавање стандарда, имајући, увек, на уму да је решавање наведених проблема на добробит ученика. Сигурно је да се не могу занемарити ни проблеми субјективне природе везани за непосредан рад наставника. Међутим, све док постоје ограничавајуће објективне околности (простор и опрема, рад у млађим разредима основне школе, стандарди везани за број ученика на часу и сл.) проблеми субјективне природе се могу њима објашњавати.

Будућа истраживања о стандардима из физичког васпитања требало би вршити у школама које имају адекватне услове за рад и онда 
закључивати о квалитету стандарда. Био би корак уназад стандарде, као и програме физичког васпитања на националном нивоу, у недоглед, усклађивати са условима рада, пре свега због тога што исходе у образовању треба прилагођавати способностима ученика.

ИЗ УЖЕГ КОНТЕКСТА УСЛОВА ЗА ИСПУЫАВАњЕ СТАНДАРДА, овОМ ПрИЛИКОМ, обратиће се пажња на школу, локалну заједницу, родитеље и наставнике физичког васпитања.

\section{Обезбеђивање функција школе}

Прва од две широке категорије стандарда, која се препознаје на националном нивоу су „Стандарди квалитета улаза, материјални, технички, просторни услови, квалитет наставних средатава и других ресурса којима се обезбеђује реализација наставе“ (Ковач-Церовић, и сар. 2004., стр. 64). Обезбеђивање стандарда квалитета улаза се, у великој мери, преноси на локалну самоуправу. Међутим, без поштовања критеријума донетих на националном нивоу и без њихове провере, тешко да стандарди могу бити остварени на ширем плану (све школе). „Установа може да почне са радом и да обавља делатност образовања и васпитања ако испуњава услове и има прописан простор опему и наставна средства“ (из Закона о основама система образовања и васпитања, члан 30, став 3, тачка 1). Иако не зависе само од ње у великом броју школа, између осталих, постоје проблеми материјалних услова за реализовање наставе (простор и опрема). Као што је то случај и са програмом физичког васпитања, тако и у стандардима провејава упутство према коме, и једне и друге треба реализовати у складу са условима рада. Ни у једној другој васпитно-образовној области - предмету нема толико произвољности колико их има у физичком васпитању. Све до ситуације у којој услова за реализовање наставе уопште нема. Решавање проблема простора и опреме у школи се, деценијама, везује за креативност наставника и програмирање у складу са условима рада. Категорија креативности наставника је, у физичком васпитању стара колико су стари и образовни програми. Међутим, када је реч о испуњавању стандарда на националном нивоу, у струци их можемо искористити и као механизам за обезбеђивење адекватних услова рада.

\section{Вертикална повезаност реализовања циљева и исхода првог и другог циклуса обавезног образовања}

Обезбеђивање вертикалне повезаности реализовања циљева и исхода првог циклуса са циљевима и исходима другог циклуса је услов за испуњавање стандарда за крај обавезног образовања и васпитања. Реализовање квалитетног физичког васпитања у млађим разредима, у великој мери зависи од плана рада школе (из Закона о основама система образовања: Аутономија установе, члан 41; Надлежности органа управљања, члан 57; Савет родитеља, члан 58; Надлежности стручног органа, тимова и педагошких колегијума, члан 67; Образовно васпитни рад, члан 87; Годишњи план рада, члан 89; Ученички парламент, члан 105; Обезбеђивање средстава за виши квалитет наставе, члан 160). Са великом лакоћом се, и у школама, у којима се физичко васпитање изводило као предметна настава у четвртом разреду, процес стручног рада „преместио“ у пети разред. Примери позитивних резултата рада у школама, у којим се настава физичког васпитања разреда у четвртом реализује, ређе у трећем разреду, а понекад и раније, као и резултати бројних истраживања спроведених у последњих десет година, магистарских теза и докторских дисертација, говоре у прилог озбиљном размататрању потребе квалитетног стручног рада са ученицима млађег школског узраста, на националном нивоу. Залажући се за овакво решење, наша струка иде укорак са решењима која се предлажу у развијеним европским земљама.

\section{Обезбеђивање повезаности школе са локалном заједницом и ангажовање родитеља}

У непрекидном инсистирању на решавању проблема који омогућавају реализовање програма физичког васпитања, у обиму и садржају релевантном за допринос правилном расту и интегралном развоју ученика свих узраста, неопходна је сарадња измећу школе, локалне заједнице, родитеља и актива наставника физичког васпитања. Локална заједница има низ законом одређених функција које су у вези са радом школе: обезбеђивање материјалних услова рада, садржаји одређених делова програма (спортске активности од интереса за локалну заједницу су 
део програма сваког разреда), усавршавање наставника... Када се ради о физичком васпитању и спортским активностима, ове функције се остварују и сарадњом са општинским секретарима за спорт који се, између осталог, баве и питањима организације школских спортских такмичења. Наставник физичкок васпитања више није усамљен и једини одговоран за реализовање циљева и исхода физичког васпитања: „Одговорност за квалитет образовања не сносе само наставници, већ и сви остали заинтересовани актери - родитељи и локална заједница“, (КовачЦеровић, и сар. 2004. стр. 39).

Министарство просвете ради на примени »Оквирног акционог плана за заштиту деце од насиља у образовно-васпитним установама». Дефинисањем Трећег специфичног циља у оквиру овог плана, у Агенди за локалне заједнице стоји да је она одговорна за Обезбеђивање превентивне и заштитне улоге школског спорта и спортских активности у заштити деце/ученика. Позитивни примери из праксе, који су остварени уз значајно учешће повезаности локалне заједнице и наставника физичког васпитања, већ постоје.

\section{Ангажовање наставника}

Наставник јесте одговоран за планирање, програмирање и управљање процесом наставе, за праћење и напредовање ученика као и за самовредновање, чији резултати постају почетак новог, коригованог циклуса планирања. У Закону о основама система образовања и васпитања, члану 118. стоји: „Задатак наставника јесте да својим компетенцијама осигура циљеве образовања и васпитања и стандарда постигнућа, уважавајући принципе образовањања, потребе и интересовања и посебне могућности детета и ученика.“ Планирање рада у коме постоји тежња да се повећа квалитет властитог рада могућно је уз постојање индикатора и стандарда, који конкретизују циљеве и исходе наставног процеса.

Квалитетно иницијално образовање и стручно усавршавање обезбеђују да наставник физичког васпитања преузме одговорност за другу, од две широке категорије стандарда, која се препознаје на националном нивоу (уколико је испуњена прва - примедба аутора), а то су: „Стандарди квалитета излаза - садржај и својство, знања, умена и вештина након завршетка школовања у целини или одређеног ни- воа школовања“ (Ковач-Церовић, и сар. 2004, стр. 64). Када је реч о квалитетном иницијалном образовању треба бити свестан чињенице да ни у једном материјалу Министарства просвете и спорта, а данас Министарства просвете, као ни у другим материјалима везаним за реформу образовања и школовање наставника, факултети спорта и физичког васпитања се не препознају као институције чији су програми, одувек били и данас су, усмерени на педагошко и теоријскометодичко оспособљавање будућих наставника. Овакав став иницира струку да се ангажује на квалитетнијем позиционирању унутар система образовања и васпитања.

ИЗ ШИРЕГ КОНТЕКСТА УСЛОВА ЗА ИСПУЊАВАњЕ СТАНДАРДА, ЗНачајно је, између осталог, имати у виду процес примене и усавршавања стандарда на националном нивоу и улогу стручних и научних радника из научне области Физичко васпитање и спорт у том процесу. Да би се стандарди применили биће потребан одређен период времена за објављивање у Службеном гласнику и обавештавање стручне јавности да су Стандарди објављени, као и за едукацију школских саветника (надзорника ...) и наставника. Сигурно је да ће, као што је то било са стручним усавршавањем наставника, у почетку бити тешкоћа. Међутим, када се у укупном контексту сагледају моћна средства која стандарди пружају настојањима за обезбеђење квалитета наставног процеса (материјални услови рада, циљеви, исходи, самовредновање и спољашње вредновање), могу се очекивати и други, значајни елементи за унапређивање самих стандарда.

Перспективно, стандарди ће обухватити и друге, за физичко васпитање релевантне исходе. За њихово формулисање биће потребно реализовање бројних пројеката који су, или директно везани за стандарде, или непосредно утичу на квалитет исхода физичког васпитања, на пример:

\section{Дефинисање нових индикатора и стандарда}

За физичко васпитање је значајно да се обухвате и други релевантни исходи, као што су стање и развој моторичких способности ученика, карактеристике постуралног статуса и карактеристике социјалног понашања ученика, које су 
у непосредној вези са реализовањем процеса физичког васпитања. Позитиван допринос физичког васпитања може се остварити уколико се има виду интегрални развој детета/ученика. У Стандардима за физичко васпитање за крај обавезног образовања, на сваком месту где је то у контексту, стоји напомена да је неопходно извршити посебна истраживања и предложити тестове за националну батерију тестова. Радна група за израду стандарда није имала релевантне податке за ову област, тако да ће уследити истраживање, које се може ослонити на бројна домаћа и страна искуства.

\section{Формирање базе података физичког васпитања}

Формирање базе података физичког васпитања унутар јединственог информационог система просвете је следећи велики пројекат који ће омогућити да се, уз параметре из база података и одговарајуће програме, процес вредновања резултата ученика, формулшу критеријуми на основу којих се ученик упућује према физичким, односно спортским активностима у којима може имати највише успеха, и чиме самовредновање и вредновање добијају пуни смисао.

\section{Пројекти усмерени на унепређивање стандарда и програма физичког васпитања.}

Реализовање пројеката везаних за унапређивање стандарда и програма физичког васпитања, у основи зависе од избора, квалитета и ажурирања унесених параметара у базу података за физичко васпитање унутар јединственог информационог система просвете, што је, опет, посебан пројектни задатак. За ове послове би била корисна сарадња на релацији: Завод за вредновање квалитета образовања и васпитања, Завод за унапређивање образовања и васпитања, факултети спорта и физичког васпитања ....

\section{Пројекти усмерени на повезивање физичког васпитања са другим делатностима које се баве превенцијом, физичким активностима и спортом}

Како би физичко васпитање било део укупних процеса којим се физичко васпитање друштвеној заједници нуди као образовно ва- спитно подручје од посебног интереса потребно је даље реализовање пројеката који повезују физичко васпитање са програмима из: Стратегије спорта која се бави и питањима образовања и васпитања путема спорта и другим питањима везаним за школу и школски спорт; Закона о спорту у коме се помињу школски спорт, кадрови и материјална инфраструктура; из докумената који говоре о доступности физичке активности и физичког васпитања свим ученицима, под једнаким условима; Оквирним акционим планом за заштиту деце од насиља у образовно-васпитним установама и другим бројним документима који могу бити основа за истраживачке пројекте.

\section{Пројекти који систематизују и пласирају у јавност досадашње резултате у научној области Физичко васпитање и спорт}

Од посебног значаја би било реализовање пројеката којима би се систематизовали значајни резултати досадашњих истраживачких пројеката и радова, до којих се у научној области Физичко васпитање и спорт дошло, и који би били представљени јавности, посебно институцијама здравства, стручним друштвима педагога, психолога, социолога, институцијама просвете и спорта, као и скупштинским телима, која се баве питањима просвете.

\section{Пројекат унапређивања организације и рада Друштва педагога физичке културе}

Реализовање пројекта усмереног према унапређивању рада Друштва педагога физичке културе и повезивању унутар овог стручног друштва, од кога, уосталом и зависи реализовање циља, исхода, испуњавање стандарда из физичког васпитања, као и самовредновања и вредновања био би додатан стимуланс за квалитетнији рад у образовно-васпитном подручју (предмету) физичко васпитање. 


\section{ЗАКЉУЧНО РАЗМАТРАЫЕ}

Стандарди пружају значајну подршку настојањима да се обезбеди и унпређује квалитет наставног процеса физичког васпитања: материјални услови рада, циљеви, исходи, самовредновање и вредновање. Они отварају и питање да ли физичко васпитање у свом називу треба да носи и одредницу образовање.

Стандарди улаза: материјални, технички, просторни услови, квалитет наставних средсатава и других ресурса којима се обезбеђује реализација наставе, су значајни ограничавајући фактори за испуњавање образовних стандарда за крај обавезног образовања.

Опште карактеристике стандарда: диференцијација, разумљивост, изводљивост и обавезност за све су, у потпуности, применљиве на стандарде у физичком васпитању. Када је реч о стандардима проверљивост спецификованих образовних исхода и фокус на темељна знања може се констатовати да се области и подобласти и индикатори који су стандардима обухваћени, односе на конкретна мерљива, за предмет специфична, знања, умења и вештине ученика. Успостављени су јасни механизми за вредновање, посебно у делу који се односи на теоријска знања о физичком вежбању и физичком васпитању и вредновању физичког вежбања и физичког васпитања од стране ученика (уверење о вредностима физичког вежбања и физичког васпитања). Због непостојања батерије тестова прихваћене на националном нивоу, у обзир нису узете карактеристике стања и развоја моторичких способности ученика, што је озбиљан недостатак стандарда. За физичко васпитање је кумулативност, као општа карактеристика стандарда, веома проблематична. Низ компетенција које би ученик требало да стекне у првом циклусу образовања, углавном није остварен, тако да се ово, неповољно, стање рефлектује на квалитет исхода на крају обавезног образовања. Због тога би било од изузетне важности да се изради и предлог стандарда из Физичког васпитања за први циклус образовања и васпитања. Наиме, стандарди, одређени исходима непосредно утичу на програм, а програм захтева компетенције наставника разредне наста- ве. Ограничавајуће околности проистичу из квалитета иницијалног образовања наставника разредне наставе, недостатка услова за рад, као и недовољног интересовања за реализовање наставе физичког васпитања.

Обезбеђивање стручног рада у млађим разредима, у великој мери зависи од школе, јер јој ce препушта могућност започињања стручног рада у зависности од плана рада школе. Друштво педагога физичке културе би требало да има своју стратегију обезбеђивања квалитетног рада са најмлађим, имајући у виду и позивајући се на обавезност у испуњавању стандарда образовања и васпитања, као и на чињеницу да одговорност за квалитет процеса физичког васпитања не сносе само наставници, већ и родитељи и локална заједница.

Наставник физичког васпитања је одговоран за стандарде квалитета излаза - знања, умења и вештина након завршетка школовања у целини или одређеног нивоа школовања. То му омогућавају квалитетно иницијално образовање и стручно усавршавање, самовредновање и вредновање.

Перспективно, стандарди ће обухватити и друге, за физичко васпитање релевантне исходе. Њихово формулисање мора бити научно засновано. Дефинисање индикатора и стандарда стања и развоја моторичких способности ученика, карактеристике постуралног статуса и социјалног понашања ученика, које су у непосредној вези са реализовањем процеса физичког васпитања захтева примену научни-истраживачке методологије.

Будућа истраживања везана за стандарде треба вршити у школама које имају адекватне материјалне услове за рад и онда закључивати о њиховом квалитету. Био би корак уназад стандарде, као и програме физичког васпитања на националном нивоу, у недоглед, усклађивати са условима рада. Такав приступ не води ка повећању квалитета физичког васпитања. Ученици су способни за много квалитетније исходе од оних, који се у данашњим условима рада постижу, што се неповољно одражава на њихов интегрални развој.

Формулисани стандарди доприносе, са једне стране мотивацији сваког наставника, ак- 
тива наставника, школе и локалне заједнице за што квалитетнији рад, а са друге стране, мотивишу ангажовање струке да сви актери у систему образовања и васпитања, коначно, сагледају значај физичке активности и физичког васпитања за дете/ученика. Предстоји реализовање низа истраживачких пројеката везаних за: формирање база података физичког васпитања унутар јединственог информационог система просвете; унапређивање стандарда и програма физичког васпитања; повезивање физичког васпитања са делатностима бројних институција и садржајима докумената који могу бити основа за истраживачке пројекте; пројекате којима би се систематизовали значајни резултати истраживачких пројеката и радова, у научном пољу Физичко васпитање и спорт и представили их широј јавности; унапређивање рада Друштва педагога физичке културе и повезивање унутар њега...
Треба бити свестан чињенице да се, веома ретко у материјалима Министарства просвете и спорта, данас Министарства просвете, као и у другим материјалима везаним за реформу образовања и школовање наставника, факултети спорта и физичког васпитања препознају као институције чији су програми, одувек били и данас су, усмерени на педагошко и теоријскометодичко оспособљавање будућих наставника. Овакав став иницира струку да се ангажује на квалитетнијем позиционирању унутар система образовања и васпитања.

Стандарди у физичком васпитању су донети. Они уважавају елементе добрих традиционалних вредности у нашем физичком васпитању и иницирају, са једне стране савремене процесе вредновања исхода, а са друге стране живу активност унутар струке и научне области Физичко васпитање и спорт.

Предавање по позиву са Петог европског и другог српског конгреса педагога физичке културе у Нишу 2009; са одобрењем организационог одбора.

\section{ЛИТЕРАТУРА}

1. Бокан, Б (2003). Елементи за расправу о реформи физичког васпитања. Кебин, В. и експертни тим 1998-2000. Стручно мишљење о Радном материјалу „физичко и здравствено васпитање“. Допис начелници Одељења за план и програм предшколског и основношколског образовања. Министарство просвете и спорта.

2. Brettschneider W-D., Brandl-Bredenbeck H.P. (2008). Physical education and education through sport in Germany. In Klein, G., Hardman, K., (Eds.). Physical Education and Sport Education in Europien Union. (pp. 145-161). Paris: Edition Revue EP.S.

3. Eurydice: Информативна мрежа образовних система у Европи (1996). Десет година реформи обавезног образовања (1984-1994) у неким европским земљама. Превод са немачког Томе, С. (2001). Београд: Министарство просвете и спорта Републике Србије.
4. Закон о основама система образовања и васпитања, Службени гласник Републике Србије 72/2009.

5. Хавелка, Н., Бауцал, А., Плут, Д., Матовић, Н., Павловић и Бабић, Д. (2002). Систем за праћење и вредновање квалитета образовања, Предлог промена и иновација (2002-2005). У Т. Ковач-Церовић, и Љ. Левков, (ур.). Квалитетно образовање за све: Пут ка развијеном друштву (стр. 149-205). Београд: Министарство просвете и спорта Републике Србије.

6. Јелинчић, Ј., Лукшић-Орландић, Т., и Ђуро= вић, С. (2007). Европеизаиија Србије. Београд: Фонд за отворено друштво.

7. Каменов, Е. (2006). Поруке и закључци научног скупа «Европске димензије реформе система образовања и васпитања». У Е. Каменов (ур.). Зборник радова са Међународног интердисциплинарног научног скупа: Европске димензије реформе система образовања и 
васпитања. (стр. 5-12). Нови Сад: Филозофски факултет, Одсек за педагогију.

8. Klein, G., \& Hardman, K. (2008). Physical Education and Sport Education in Europien Union. Paris: Edition Revue EP.S.

9. Ковач-Церовић, Т., Граховац, В, Станковић, Д., Вуковић, Н., Игњатовић, С., Шћепановић, Д. и сар. (2004). Квалитетно образоване за све: Изазови реформи образовања у Србији. Београд: Министарство просвете и спорта Републике Србије.

10. Министарство просвете Републике Србије (2008): Оквирни акциони план за превенцију насиља у образовно-васпитним установама, Београд.

11. Правилник о наставном плану и програму за седми разред основног образовања и васпитања, Просветни гласник Републике Србије, 6/2009.
12. Радовановић, Ђ., руководилац пројекта (1996-2000). Ефекти диференциране наставе физичког васпитања на психосоматски статус деце и омладине, Министарства за науку и технологију Републике Србије. Универзитет у Новом Саду, Факултет физичке културе.

13. Репић-Ћујић, В., Гортнар, 3., Вишњић, Д., Радисављевић, С., Лепеш, Ј., и Зечевић, С. (2009). Образовни стандарди за крај обавезног образовања, Физичко васпитање. Београд: Министарство просвете Републике Србије, Завод за вредновање квалитета образовања и васпитања (www.ceo.edu.rs).

14. Чарапић, Г.У. (2009). Образовни стандарди за крај обавезног образовања, Београд: Министарство просвете и спорта Републике Србије, Завод за вредновање квалитета образовања и васпитања (www.ceo.edu.rs). 